\title{
FERMENTATIVE AND MICROBIOLOGICAL PROFILE OF MARANDU-GRASS ENSILED WITH CITRUS PULP PELLETS
}

\author{
Thiago Fernandes Bernardes*; Ricardo Andrade Reis; Andréia Luciane Moreira \\ UNESP/FCAV - Depto. de Zootecnia, Via de Acesso Prof. Paulo Donato Castellane, s/n - 14884-900 - Jaboticabal, \\ SP - Brasil. \\ *Corresponding author <tfbernardes@yahoo.com>
}

\begin{abstract}
High-wet roughages with low content of soluble carbohydrates, such as tropical grasses, should be inappropriate for producing silages of adequate quality. This study aimed to evaluate the fermentative and microbiological profiles of Marandu-grass ensilaged with pelleted citric pulp (PCP). Brachiaria brizantha (Hochst ex. A. Rich) Stapf cv. Marandu with 58 days of vegetative growth was harvested for producing experimental silages in PVC silos provided with Bünsen valves and density capacity of $900 \mathrm{~kg} \mathrm{~m}^{-3}$. Treatments were three PCP levels (0, 50 and $100 \mathrm{~g} \mathrm{~kg}^{-1}$ of fresh forage) and seven times (1, 4, 7, 14, 21, 28 and 56 days) after sealing. PCP inclusion increased soluble carbohydrate concentrations by 15 to $20 \%$ and reduced $\mathrm{pH}$ (5.3 to 4.2) and $\mathrm{N}-\mathrm{NH}_{3}$ levels of experimental silages. An increase of the population size of the enterobacterium (mean of $3 \mathrm{CFU} \mathrm{g}^{-1}$ ) was observed only at the first day of fermentation, small growth (mean $0.5 \mathrm{of} \mathrm{CFU} \mathrm{g}^{-1}$ ) of clostridium and the dominance of homo in relation to hetero-fermentative bacteria. Citric pulp addition during Marandu-grass ensilage was benefic, its utilization being recommended, especially when associated with economical advantages.
\end{abstract}

Key words: additive, bacteria, fermentation, tropical grass, silage

\section{PERFIL FERMENTATIVO E MICROBIOLÓGICO DO CAPIM- MARANDU ENSILADO COM POLPA CÍTRICA PELETIZADA}

\begin{abstract}
RESUMO: Forragens com alta umidade e baixa concentração de carboidratos solúveis, como é o caso dos capins tropicais, podem conduzir a condições desfavoráveis para a produção de silagens de qualidade satisfatória. Esse estudo objetivou conhecer o perfil fermentativo e microbiológico de silagens de capimMarandu [Brachiaria brizantha (Hochst ex. A. Rich) Stapf cv. Marandu], colhido com 58 dias de crescimento, aditivadas com polpa cítrica peletizada (PCP),. Foram utilizados silos experimentais de PVC adaptados com válvula do tipo Bunsen, tendo a silagem atingindo densidade de $900 \mathrm{~kg} \mathrm{~m}^{-3}$. Os tratamentos foram constituídos por três proporções de $\mathrm{PCP}\left(0,50 \mathrm{e} 100 \mathrm{~g} \mathrm{~kg}^{-1}\right.$ em relação a matéria natural $)$ e sete tempos de abertura após a ensilagem $(1,4,7,14,21,28$ e 56 dias). A presença de PCP aumentou os teores de CHOs em 15 a $20 \%$, reduziu o $\mathrm{pH}(5,3$ para 4,2$)$ e diminuiu as concentrações de $\mathrm{N}-\mathrm{NH}_{3}$. Houve crescimento da população de enterobactérias somente durante o primeiro dia de fermentação (média $3 \mathrm{UFC}^{-1}$ ), pequeno desenvolvimento de clostrideos (média $0,5 \mathrm{UFC} \mathrm{g}^{-1}$ ) e dominância de bactérias homo em relação às heterofermentativas, para os três tratamentos estudados. A adição de polpa cítrica durante a ensilagem do capim-Marandu foi benéfica, podendo ser recomendada desde que haja benefício econômico na sua adoção.

Palavras-chave: aditivo, bactéria, fermentação, gramínea tropical, silagem
\end{abstract}

\section{INTRODUCTION}

In spite of the high productive potential of tropical grasses, as Brachiaria brizantha cv. Marandu, which might reach 100-150 t of fresh matter ha ${ }^{-1}$ year $^{-1}$ in intensive systems, a great season variation is observed during the year. An alternative for reducing this problem is ensilage part and/or the excess of forage intensively produced during rainy season. It permits forage storage in amounts and quality to be used for animal feeding during the dry season.

Until recently, the lack of proper machines for cutting high productive tropical grasses was considered a putative reason for not using tropical grasses in ensilages. During the last 15 years some national companies have, however, developed and produced equipment with higher operational capacity and, consequently, many producers have started to ensilage tropical grasses as an alternative of roughage supplementation during dry season (Balsalobre et al., 2001).

Tropical grasses are susceptible to losses during ensilage due to their buffer capacity, humidity higher than $70 \%$ and low content of soluble carbohydrate (Balsalobre et al., 2001). These characteristics prejudice lactic acid production and, consequently, $\mathrm{pH}$ reduction in silages, which results in an inefficient fermentative process 
(Woolford, 1984). The use of absorbent material, such as citric pulp, promotes an increase of the dry matter content of the silage and guarantees improvement of fermentation conditions.

This study aimed to supply information on how pelleted citric pulp changes the fermentative process in silages of Marandu grass, considering the undesirable conditions for fermentation related to this grass species.

\section{MATERIAL AND METHODS}

\section{Experimental Conditions}

The trial was carried out at Jaboticabal SP, Brazil, at $21^{\circ} 15^{\prime} 22^{\prime}$ ' $\mathrm{S}$ and $48^{\circ} 18^{\prime} 58^{\prime}$ ' $\mathrm{W}$ with $595 \mathrm{~m}$ altitude. The climate type is Cwa - mesothermic with dry winter - according to Köppen's International System, with annual means of maximum and minimum temperatures of $22.3^{\circ} \mathrm{C}$ and $15.2^{\circ} \mathrm{C}$, respectively. Mean rainfall is 1400 $\mathrm{mm}$, with $85 \%$ of the rain falling during the months of October and March.

\section{Forage Harvest}

Fertilization with $50 \mathrm{~kg} \mathrm{ha}^{-1} \mathrm{~N}$ was made in November of 2001, when the Marandu grass was harvested for silage production. Another application of $50 \mathrm{~kg} \mathrm{ha}^{-1}$ $\mathrm{N}$ was made in January of 2002, just after cutting, in order to make forage size uniform.

March 25, 2002 with 58 days of vegetative growth, the grass was harvested with a $\mathrm{JF}^{\circledR}$ harvester (Z10 model) regulated to cut $15 \mathrm{~cm}$ above soil surface, with particle size around 2 to $5 \mathrm{~cm}$.

\section{Ensilage Process}

Forage was submitted to the following treatments: Marandu-grass ensilage directly after cutting; Marandugrass ensilage with $50 \mathrm{~g} \mathrm{~kg}^{-1}$ of pelleted citric pulp (PCP) and Marandu-grass ensilage with $100 \mathrm{~g} \mathrm{~kg}^{-1}$ of PCP, with basis on fresh matter. PCP addition was made after its homogenization with forage and before silo filling. Silages were evaluated in relation to their fermentation profiles at 1, 4, 7, 14, 21, 28 and 56 days after sealing.

The 63 experimental PVC silos had $50 \mathrm{~cm}$ of height and $10 \mathrm{~cm}$ of diameter and were provided with PVC lids for complete fence. Each silo had a Bunsen valve at the end for gas escape. Forage was compacted using iron sticks for pressing $10-\mathrm{cm}$ layers until reaching the density of $900 \mathrm{~kg} \mathrm{~m}^{-3}$. After final forage compaction, silos were sealed with adhesion of plastic tape and stored at room temperature in a protected place.

\section{Chemical Analyses}

Contents of dry matter (DM) and crude protein (CP) were determined according to AOAC (1980). To avoid acid detergent fiber (ADF) contamination by pectin, the sequential method was chosen to estimate neutral detergent fiber (NDF), ADF and lignin (Robertson \&
Van Soest, 1981). Cellulose levels were determined using 72\% sulfuric acid (Van Soest, 1994). Both hemicellulose and lignin contents were calculated by difference between NDF and ADF; and between ADF and cellulose, respectively. Residues of NDF and ADF were analyzed to estimate nitrogen binding to NDF (N-NDF/total N) and to $\mathrm{ADF}(\mathrm{N}-\mathrm{ADF} /$ total N). Fraction B3 (proposed by Cornell model) was determined subtracting N-ADF from N-NDF. Levels of soluble carbohydrates (CHOs) were calculated according to Johnson et al. (1966). Dry matter in vitro digestibility (DMIVD) was performed following Tilley \& Terry (1963) methodology. Buffering power was measured according to Playne \& McDonald (1966). Contents of ammonia nitrogen $\left(\mathrm{NH}_{3}\right.$ /total $\left.\mathrm{N}\right)$ were measured following AOAC (1980). For $\mathrm{pH}$ a measuring equipment (Silva, 1998) was used.

\section{Microbiological analysis}

Silage samples were prepared before microbiological analysis by a previous dilution in sterile saline solution: $25 \mathrm{~g}$ of silage (fresh matter) in $225 \mathrm{~mL}$ of saline solution ( $8.5 \mathrm{~g}$ of $\mathrm{NaCl} \mathrm{L}{ }^{-1}$ of distillated water). After shaking, $10 \mathrm{~mL}$ of the extract were taken for further dilutions. From diluted extracts $\left(10^{-1}\right.$ to $\left.10^{-5}\right)$ plates were prepared with specific medium for each studied microorganism (Bernardes et al., 2002).

Counting of total lactobacilli was performed according to Jonsson (1991). In this case, the Lactobacilli MRS Broth (Difco) was used as growth medium, the Petri plates being incubated at $35^{\circ} \mathrm{C}$ per three days under anaerobic conditions using a Gas-pack bottle. Classification of lactic-acid bacteria in homo or hetero-fermentative was made according to McDonald et al. (1987), the cultures being incubated at $30^{\circ} \mathrm{C}$ for three days under the same conditions described above. Presence of clostrides was determined following Tosi et al. (1982). The Reinforced Clostridial Agar (Oxoid) as growth medium was used and cultures were incubated at $30^{\circ} \mathrm{C}$ for four days under anaerobic conditions. The Violet Red Bile Agar (Oxoid) was used for enterobacterium growth as culture medium with aerobic incubation for three days at $35^{\circ} \mathrm{C}$, according to Jonsson (1991).

\section{Experimental design and statistical analysis}

The experimental design was completely randomized with three replicates and split-plot parcels. Treatments were the parcels and times the sub-parcels. Data were analyzed through ESTAT, a statistical program developed at the Department of Exact Sciences of FCAV/ UNESP, using variance analysis procedures. Means were compared by the Tukey test $(P<0.05)$.

\section{RESULTS AND DISCUSSION}

The forage presented features of tropical grasses, like high levels of moisture and low content of soluble 
carbohydrates (Table 1). Ribeiro et al. (2002), studying silage of Brachiaria decumbens Stapf. cv. Basilisk harvested after 56 days of vegetative growth $255 \mathrm{~g} \mathrm{~kg}^{-1}$ of $\mathrm{DM}$ and $12 \mathrm{~g} \mathrm{~kg}^{-1}$ of CHOs before ensilage.

The high levels of structural carbohydrate and fiber-binding nitrogen (Table 1) are in accordance with the forage species and also, with the late growth stage at the moment of ensilage (58 days). High precipitation of cell wall components resulted in low dry matter digestibility (46.2\%). Reis (2000), evaluating the chemical composition of Marandu-grass in relation to its age at cutting, found that at 60 days of vegetative age plant had $837 \mathrm{~g}$ $\mathrm{kg}^{-1}$ of NDF, $435 \mathrm{~g} \mathrm{~kg}^{-1}$ of ADF, $56 \mathrm{~g} \mathrm{~kg}^{-1}$ of lignin, 312 $\mathrm{g} \mathrm{kg}^{-1}$ of N-NDF and $265 \mathrm{~g} \mathrm{~kg}^{-1}$ of N-ADF.

High content of DM and CHOs was found in the PCP, which justify its use as an additive during ensilage of tropical grasses (Table 2). Hall (2001), evaluating the chemical composition of PCP in 79 trials, found levels of CHOs ranging from 125 to $402 \mathrm{~g} \mathrm{~kg}^{-1}$.

\section{Fermentative Profile}

Levels of CHOs in silages was not affected $(P<$ 0.05 ) by PCP addition but, sugar content increased (Figure 1), increasing substrate availability for microbial fermentation in the silage. The level of CHOs decreased with the increase of the ensilage period. Reductions $(P<0.05)$ in $\mathrm{CHO}$ content were observed for the control silage from the first to the fourteenth day; for silage with $50 \mathrm{~g} \mathrm{~kg}^{-1}$ of PCP from the first to the seventh day; and for silage with $100 \mathrm{~g} \mathrm{~kg}^{-1}$ of PCP from the first to the fourth day after sealing.

Table 1 - Chemical composition of Marandu-grass harvested at 58 days of vegetative age.

\begin{tabular}{|c|c|}
\hline Traits & Average \\
\hline $\mathrm{DM}\left(\mathrm{g} \mathrm{kg}^{-1}\right)$ & 229 \\
\hline CHOs $\left(\mathrm{g} \mathrm{kg}^{-1} \mathrm{MS}\right)$ & 11 \\
\hline Buffering power (e mg $100 \mathrm{~g}^{-1} \mathrm{DM}$ ) & 21.6 \\
\hline $\mathrm{pH}$ & 5.9 \\
\hline $\mathrm{NH}_{3}\left(\mathrm{~g} \mathrm{~kg}^{-1}\right.$ total $\left.\mathrm{N}\right)$ & 36 \\
\hline $\mathrm{CP}\left(\mathrm{g} \mathrm{kg}^{-1} \mathrm{DM}\right)$ & 107 \\
\hline $\mathrm{N}-\mathrm{NDF}\left(\mathrm{g} \mathrm{kg}^{-1}\right.$ total $\left.\mathrm{N}\right)$ & 456 \\
\hline $\mathrm{N}-\mathrm{ADF}\left(\mathrm{g} \mathrm{kg}^{-1}\right.$ total $\left.\mathrm{N}\right)$ & 104 \\
\hline $\mathrm{B} 3\left(\mathrm{~g} \mathrm{~kg}^{-1}\right.$ total $\left.\mathrm{N}\right)$ & 348 \\
\hline NDF ( g kg$\left.^{-1} \mathrm{DM}\right)$ & 752 \\
\hline $\mathrm{ADF}\left(\mathrm{g} \mathrm{kg}^{-1} \mathrm{DM}\right)$ & 458 \\
\hline Hemicellulose $\left(\mathrm{g} \mathrm{kg}^{-1} \mathrm{DM}\right)$ & 294 \\
\hline Cellulose $\left(\mathrm{g} \mathrm{kg}^{-1} \mathrm{DM}\right)$ & 408 \\
\hline Lignin $\left(\mathrm{g} \mathrm{kg}^{-1} \mathrm{DM}\right)$ & 49 \\
\hline DMIVD (\%) & 46.2 \\
\hline \multicolumn{2}{|c|}{$\begin{array}{l}\mathrm{DM}=\text { dry matter; } \mathrm{CHOs}=\text { solubre carbohydrates; } \mathrm{CP}=\text { crude } \\
\text { protein; } \mathrm{N}-\mathrm{NDF}=\text { nitrogen binding to NDF; } \mathrm{N}-\mathrm{ADF}=\text { nitrogen } \\
\text { biding to } \mathrm{ADF} ; \mathrm{B} 3=\text { fraction } \mathrm{B} 3 \text { (proposed by Cornell model); } \\
\mathrm{NDF}=\text { neutral detergent fiber; } \mathrm{ADF}=\text { acid detergent fiber; DMIVD } \\
=\text { dry matter in vitro digestibility. }\end{array}$} \\
\hline
\end{tabular}

Evaluating the fermentative profile of Tanzâniagrass (Panicum maximum Jacq. cv. Tanzânia) with 60 days of regrowth ensilaged with pelleted citric pulp, Silva (2002) found a slight reduction in CHOs from 30 to 40 days after sealing, a complete consumption of silage soluble carbohydrates being observed after 60 days. The level of CHOs was higher than that observed in our study (11 vs $25 \mathrm{~g} \mathrm{~kg}^{-1} \mathrm{DM}$ ). Also, Silva (2002) reported that the addition of $120 \mathrm{~g} \mathrm{~kg}^{-1}$ of PCP to the forage increased in three percent the level of CHOs, evidencing the effect of citric pulp on the increase of the fermentable carbohydrate content in the forage.

Tropical grasses have low content of CHOs, which prejudice the production of lactic silages. However, during the initial phase of the ensilage process vegetal cell enzymes are capable to disrupt the cell structure to turn the nutrients required for fermentation available (Winters et al., 1987 and Chamberlain, 1987). In studies with Italian ryegrass (Lolium multiflorum), after 6-7 days of ensilage an increase of $30 \%$ in the soluble carbohydrate level was observed due to ruptures of chemical bonds within structural carbohydrates, mainly hemicellulose (Chamberlain, 1987). This author pointed out that soluble carbohydrate of forages might sub-estimate the

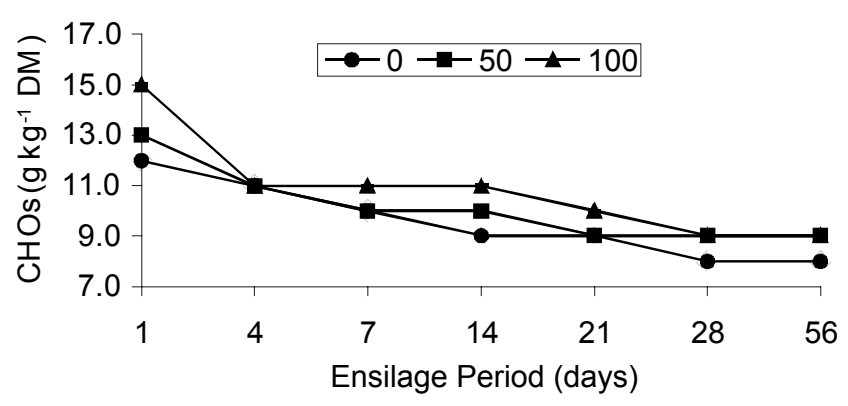

Figure 1 - Temporal variations in levels of soluble carbohydrate (CHOs) in Marandu-grass ensilaged with 0, 50 and 100 $\mathrm{g} \mathrm{kg}^{-1}$ of pelleted citric pulp.

Table 2 - Chemical composition of pelleted citric pulp.

\begin{tabular}{lc}
\hline Traits & Average \\
\hline $\mathrm{DM}\left(\mathrm{g} \mathrm{kg}^{-1}\right)$ & 885 \\
$\mathrm{CHOs}\left(\mathrm{g} \mathrm{kg}^{-1} \mathrm{DM}\right)$ & 186 \\
$\mathrm{CP}\left(\mathrm{g} \mathrm{kg}^{-1} \mathrm{DM}\right)$ & 78 \\
$\mathrm{NDF}\left(\mathrm{g} \mathrm{kg}^{-1} \mathrm{DM}\right)$ & 284 \\
ADF $\left(\mathrm{g} \mathrm{kg}^{-1} \mathrm{DM}\right)$ & 227 \\
Hemicellulose $\left(\mathrm{g} \mathrm{kg}^{-1} \mathrm{DM}\right)$ & 57 \\
Cellulose $\left(\mathrm{g} \mathrm{kg}^{-1} \mathrm{DM}\right)$ & 215 \\
Lignin $\left(\mathrm{g} \mathrm{kg}^{-1} \mathrm{DM}\right)$ & 12 \\
DMIVD $\%)$ & 72.4 \\
\hline
\end{tabular}

$\mathrm{DM}=$ dry matter; $\mathrm{CHO}=$ solubre carbohydrates $\mathrm{CP}=$ crude protein; $\mathrm{NDF}=$ neutral detergent fiber; $\mathrm{ADF}=$ acid detergent fiber; DMIVD $=$ dry matter in vitro digestibility. 
availability of substrates for lactic fermentation but, even with levels of CHOs lower than that recommended (100$\left.150 \mathrm{~g} \mathrm{~kg}^{-1}\right)$ is possible to produce silages of acceptable quality.

Inclusion of PCP resulted in lower $(P<0.05)$ values of the $\mathrm{pH}$ in silages (Figure 2). Decreases were observed from the first to the fourth day of the ensilage period in the three experimental treatments $(P<0.05)$. From the fourth to the last day of the ensilage period ( 56 days) the $\mathrm{pH}$ was stable. The mean value of $\mathrm{pH}$ during stable period was 4.5 in the control, 4.2 in silage with $50 \mathrm{~g} \mathrm{~kg}^{-1}$ of PCP and 4.0 in silage with $100 \mathrm{~g} \mathrm{~kg}^{-1}$ of PCP.

Final $\mathrm{pH}$ and velocity of its decrease during the fermentative process might determine the types of microorganisms which grow and dominate the silo environment. Considering only $\mathrm{pH}$ as a limiting factor for microbial growth, we might suppose that the three evaluated silages had a good fermentation with adequate $\mathrm{pH}$ to avoid undesirable microorganism growth, mainly those of the Clostridium genus.

Also Silva (2002), evaluating $\mathrm{pH}$ in silages of Tanzânia-grass with PCP $\left(0,30,60,90\right.$ and $\left.120 \mathrm{~g} \mathrm{~kg}^{-1}\right)$, found a $\mathrm{pH}$ stabilization from the third to the sixtieth day of the ensilage period within all treatments.

Carbohydrate supplying by PCP probably helps to reduce silage $\mathrm{pH}$. Therefore, with the increase of nutrient availability for lactic-acid bacteria the level of lactic acid produced should be higher in silages with PCP. According to Corlett Jr. \& Brown (1980), lactic acid produced in silages increase $\mathrm{H}^{+}$concentration reducing $\mathrm{pH}$ until levels not tolerated by undesirable bacteria.

Treatments had effect $(P<0.05)$ on $\mathrm{NH}_{3}$ production, which varied with ensilage time. With the increase of inclusion levels of PCP the $\mathrm{NH}_{3}$ level was reduced (Figure 3) probably due to the faster decrease of $\mathrm{pH}$ that limited Clostridium growth. These results are in accordance with Igarasi (2002), who also evaluated PCP (150 $\left.\mathrm{g} \mathrm{kg}^{-1}\right)$ as an additive in Tanzânia-grass silages $\left(20 \mathrm{~g} \mathrm{~kg}^{-1}\right)$ and verified that this amount of PCP increased dry matter content to $299 \mathrm{~g} \mathrm{~kg}^{-1}$ and water activity to 0.96 , which reduced $\mathrm{NH}_{3}$ levels in relation to control silages. This author considered the main factors responsible for ammonia production as

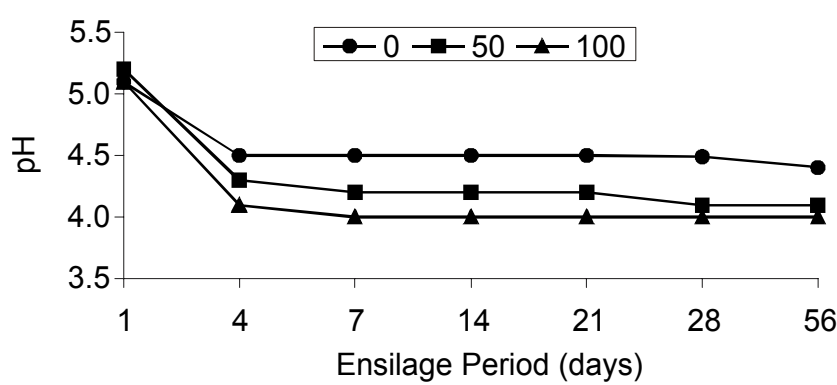

Figure 2 - Temporal variation of $\mathrm{pH}$ in Marandu-grass silages supplemented with 0,50 and $100 \mathrm{~g} \mathrm{~kg}^{-1}$ of pelleted citric pulp. being the reduction of water activity and the supply of $\mathrm{CHOs}$ by PCP, once clostrides are susceptible to high osmotic pressure and acid conditions $(\mathrm{pH}<4.2)$.

The increase $(P<0.05)$ of the $\mathrm{NH}_{3}$ level from the first to the fifty-sixth day of ensilage (Figure 3) was also found by Silva (2002) for Tanzânia-grass silages with PCP. In this last case, there was a linear increase in ammonia production and there was no tendency for stabilization. On the other hand, levels of $\mathrm{NH}_{3}$ are considered low within a group of silages with desirable fermentations (lower than $15 \mathrm{~g} \mathrm{~kg}^{-1} /$ total $\mathrm{N}$ ).

Ammonia production might be a result of the low content of soluble carbohydrates in the substrate, which should lead lactic-acid bacteria to use amino acids as energy source for growth and metabolism. In general, lactic-acid bacteria do not metabolize protein but, they do when CHOs is a limiting factor (McGechan, 1989 and McDonald et al., 1991). Their ability for fermenting amino acids is restricted to serine and arginine. Arginine fermentation results in ornitin, $\mathrm{CO}_{2}$ and $\mathrm{NH}_{3}$. Serine fermentation results in acetone, $\mathrm{CO}_{2}$ and $\mathrm{NH}_{3}$.

\section{Microbiologic Profile}

Enterobacterium growth was observed in all treatments during the first to the fourth day of fermentation. After this period, all groups of enterobacteria was found in all experimental silages (Figure 4), probably because $\mathrm{pH}$ inhibited enterobacterium growth, since they are sen-

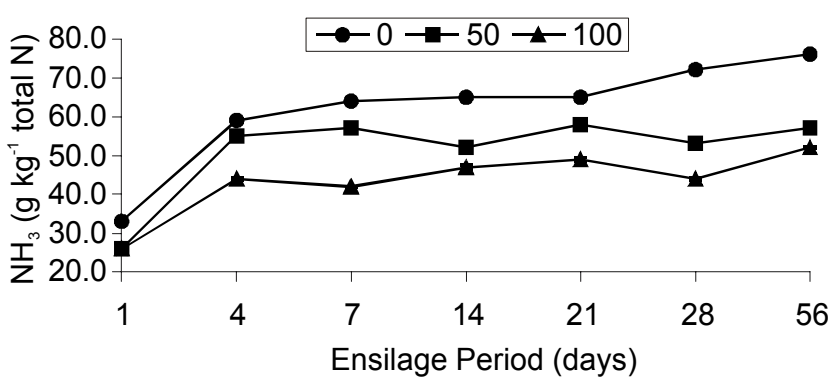

Figure 3 - Temporal variation of ammonia nitrogen levels $\left(\mathrm{NH}_{3} /\right.$ total $\mathrm{N}$ ) in Marandu-grass silages supplemented with 0 , 50 and $100 \mathrm{~g} \mathrm{~kg}^{-1}$ of pelleted citric pulp.

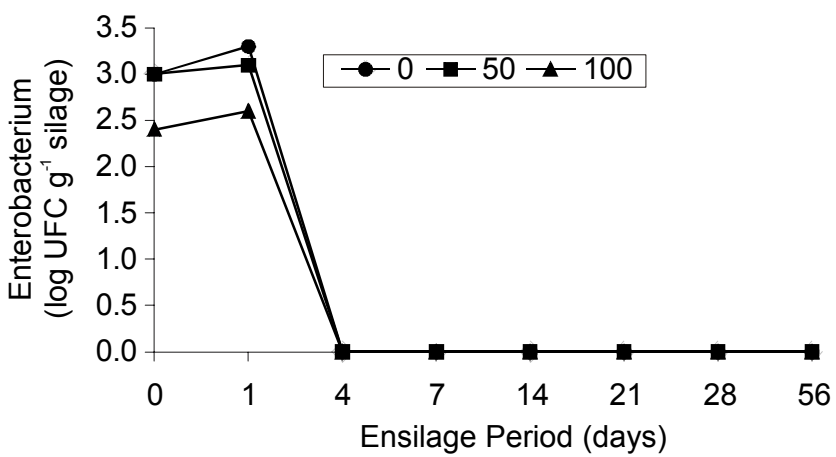

Figure 4 - Enterobacterium occurrence during the fermentation process of Marandu-grass silage with 0,50 and $100 \mathrm{~g}$ $\mathrm{kg}^{-1}$ of pelleted citric pulp. 
sible to $\mathrm{pH}$ lower than 5.0 and from the fourth day after sealing silage $\mathrm{pH}$ was around 4.5 (Figure 2). In general, enterobacteria grow very fast during the first days of ensilage and with environmental acidification their growth is intensely reduced (Ostling \& Lindgren, 1995).

Another factor related to the capacity of enterobacterium survive after the first day of ensilage is the low oxygen tension of silage. Microorganisms are classified in aerobic, optional anaerobic or anaerobic according to their capacity for oxygen utilization as final receptor of electrons in the respiratory metabolism (Montville, 1997). Facultative anaerobic bacteria, such as enterobacterium, can use oxygen as an electron receptor but when oxygen is absent they have an alternative way, in which organic composts are successively oxy-reduced, but with abrupt changes in metabolism. Because of this, these bacteria are capable to grow under lower oxy-reduction conditions, but they do not overcome anaerobic environment, especially that reached by the high particle compaction during the ensilage process responsible by a silage density of $900 \mathrm{~kg} \mathrm{~m}^{-3}$.

The PCP addition increased $(P<0.05)$ population of clostridium at the beginning of the ensilage process (Figure 5) probably due to additive contamination with bacterium spores. However, during the fermentation period this microorganism population decreased possibly because of the benefic effect of PCP addition, characterized by an increase of dry matter and a reduction of water activity. According to Dodds \& Austin (1997), the minimum levels of water activity that allow the growth of some species of clostridium are around 0.95 to 0.97 . Our results confirmed reports of Igarasi (2002), who found values of 0.94 to 0.98 for grass-silages produced during dry and rainy seasons, respectively. This same author found lower contents of ammonia nitrogen in silages produced during the dry season, indicating a reduction of the clostridium activity in dryer silage.

During the first twenty-four hours of fermentation, clostridium population increased $(P<0.05)$ in silages with 0 and $50 \mathrm{~g} \mathrm{~kg}^{-1}$ of PCP and was maintained stable in silages with $100 \mathrm{~g} \mathrm{~kg}^{-1}$ of PCP. From the first to the fourth day of ensilage, the clostridium population suffered an accentuated decrease in all treatments and was maintained stable until the fourteenth day in the treatment with $0 \mathrm{~g} \mathrm{~kg}^{-1}$ of PCP and until the twenty-eighth day in treatments with 50 and $100 \mathrm{~g} \mathrm{~kg}^{-1}$ of PCP $(P<0.05)$. This behavior might be explained in function of the sensitivity of these microorganisms to decreases of $\mathrm{pH}$, which diminished after the fourth day of ensilage in all treatments (Figure 2). Instabilities in the clostridium population were found from the fourteenth day in silages with $0 \mathrm{~g} \mathrm{~kg}^{-1}$ of PCP and from the twenty-eighth day in silages with 50 and $100 \mathrm{~g} \mathrm{~kg}^{-1}$ of PCP.

Although the increase of the clostridium population during the last ensilage times the number of colonyforming units (CFU) were considered low during the whole period ( 0.2 to $0.8 \mathrm{CFU} \mathrm{g}^{-1}$ silage). This fact might be proved by the low levels of $\mathrm{NH}_{3}$ found in all experimental silages (Figure 3).

The PCP addition promoted a slight numeric increase of the lactobacillus population at the beginning of the ensilage processes and during the fermentation period $(P>0.05)$. At the first twenty-four hours of the ensilage period the population of lactobacilli increased in all experimental silages, with a tendency to fall until the fourth day and to increase from the fourth to seventh day of ensilage (Figure 6). After the seventh day there was stabilization in population growth until the twenty-first day. After this period, the population started to increase again until the fifty-sixth day.

The number of lactic-acid bacteria necessary to reduce abruptly silage $\mathrm{pH}$ is around $8.0 \log \mathrm{CFU} \mathrm{\textrm {g } ^ { - 1 } \text { of }}$ silage (McDonald et al., 1991). However, many authors evaluating silages made from different crops have reported initial populations from 3.7 to $6.3 \log \mathrm{CFU} \mathrm{g} \mathrm{g}^{-1}$ of silage with good conservation of ensilaged forage (Higginbotham et al., 1998; Driehuis et al., 2001; Whiter \& Kung Jr., 2001). Considering our data, population size of lactic-acid bacteria at the beginning of ensilage was

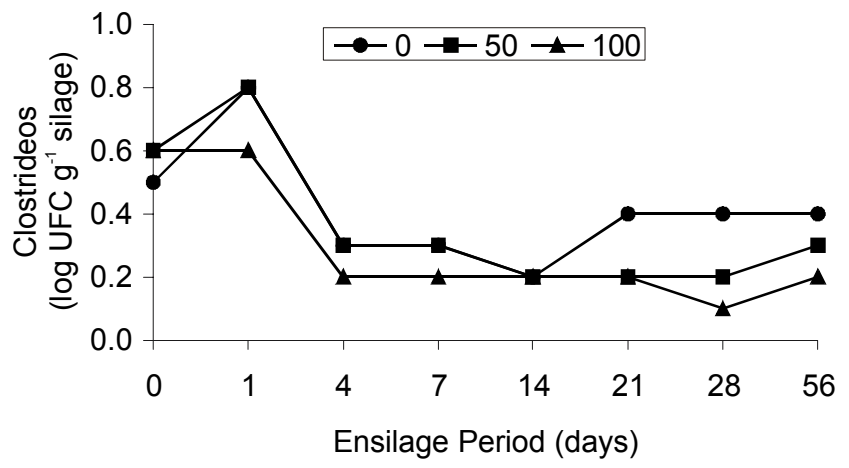

Figure 5 - Presence of clostrides during Marandu-grass silage fermentation with 0,50 and $100 \mathrm{~g} \mathrm{~kg}^{-1}$ of pelleted citric pulp.

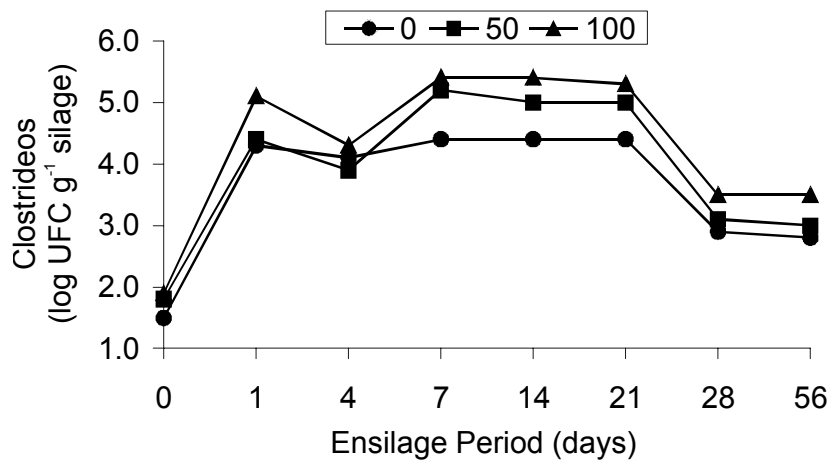

Figure 6 - Occurrence of lactobacilli during fermentation of Marandu-grass silages with 0,50 and $100 \mathrm{~g} \mathrm{~kg}^{-1}$ pelleted citric pulp.

Sci. Agric. (Piracicaba, Braz.), v.62, n.3, p.214-220, May/June 2005 


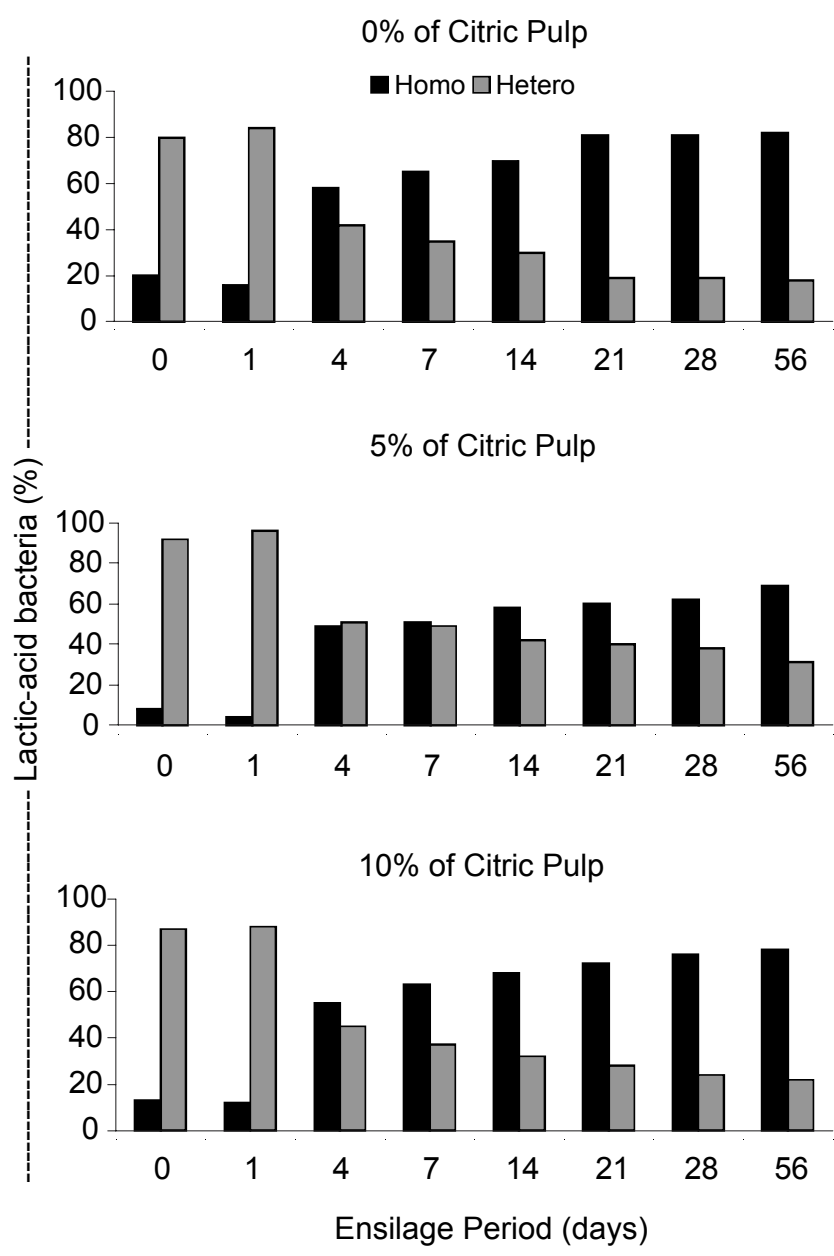

Figure 7 - Occurrence of homo and hetero-fermentative bacteria during the fermentation of Marandu-grass silages with 0,50 and $100 \mathrm{~g} \mathrm{~kg}^{-1}$ of pelleted citric pulp.

not enough for an effective production of lactic acid, but from the first day of fermentation, this microorganism population increased enough to promote a fast silage acidification.

From zero to one day after sealing there was predominance of hetero-fermentative bacteria in all treatments (Figure 7). Four days after sealing, there was an accentuated increase of homo-fermentative bacteria until the fifty-sixth day. At the end of the fermentation period, 80,60 and $70 \%$ of bacteria, on the average, were classified as homo-fermentative for treatments with 0,50 and $100 \mathrm{~g} \mathrm{~kg}^{-1}$ of PCP, respectively. This result agrees with McDonald et al. (1991), who reported that during the fermentative process the population of homo and hetero-fermentative bacteria varies according to environmental conditions.

\section{REFERENCES}

ASSOCIATION OF OFFICIAL AGRICULTURAL CHEMISTS. Official methods of analyses of the AOAC. 13.ed. Washington, 1980. 1015p.
BALSALOBRE, M.A.A.; NUSSIO, L.G.; MARTHA Jr., G.B. Controle de perdas na produção de silagens de gramíneas tropicais. In: REUNIÃO ANUAL DA SOCIEDADE BRASILEIRA DE ZOOTECNIA. 38., Piracicaba, 2001 Anais. Piracicaba: SBZ, 2001. p.890-911.

BERNARDES, T.F.; SILVEIRA, R.N.; COAN, R.M. REIS, R.A.; MOREIRA, A.L.; SCHOCKEN-ITURRINO, R.P. Características fermentativas e presença de leveduras na cana-de-açúcar crua ou queimada ensilada com aditivo. In: REUNIÃO ANUAL DA SOCIEDADE BRASILEIRA DE ZOOTECNIA. 39., Recife, 2002 Anais. Recife: SBZ, 2002. 1 CD ROM.

CHAMBERLAIN, D.G. The silage fermentation in relation to the utilization of nutrients in the rumen. Process Biochemistry, v.1, p.60-63, 1987.

CORLETT Jr., D.A.; BROWN, M.H. pH and acidity. In: INTERNATIONAL COMISSION MICROBIOLOGICAL SPECIFICATIONS OF FOODS. Microbial ecology of foods: Factors affecting life and death of microorganisms. New York: Academic Press, 1980. cap.1, p.92-111.

DODDS, K.L.; AUSTIN, J.W. Foodborne pathogenic bacteria: Clostridium botulinum. In: DOYLE, M.P.; BEUCHAT, L.R.; MONTEVILLE, T.J. (Ed.) Food microbiology: Fundamentals and frontiers. Washington: ASM Press, 1997. cap.15, p.288-304.

DRIEHUIS, F.; OUDE ELFERINK, W.H.; VAN WIKSELAAR, P.G. Fermentation characteristics and aerobic stability of grass silage inoculant with Lactobacillus buchneri, with or without mofermentative lactic acid bacteria. Grass and Forage Science, v.56, p.330-343, 2001.

HALL, M.B. Recent advanced in non-ndf carbohydrates for the nutrition of lactating cows. In: SIMPÓSIO INTERNATIONAL EM BOVINOCULTURA DE LEITE, Lavras, 2001. Anais. Lavras: FAEPE, 2001. cap.8, p.139-148.

HIGGINBOTHAM, G.E.; MUELLER, S.C.; BOLSEN, K.K.; DePETERS, E.J. Effects of inoculants containing propionic acid bacteria on fermentation and aerobic stability of corn silage. Journal of Dairy Science, v.81, p.2185-2192, 1998.

IGARASI, M.S. Controle de perdas na ensilagem de capim-Tanzânia (Panicum maximum Jacq. Cv. Tanzânia) sob os efeitos do teor de matéria seca, do tamanho de partícula, da estação do ano e da presença do inoculante bacteriano. Piracicaba: USP/ESALQ, 2002. 132p. (Dissertação - Mestrado).

JOHNSON, R.R.; BALWANI, T.L.; JOHNSON, L.J. Corn plant maturity. II. Effect on in vitro cellulose digestibility and soluble carbohydrate content. Journal of Animal Science, v.25, p.617-623, 1966.

JONSSON, A. Growth of clostridium tyrobutiricum during fermentation and aerobic deterioration of grass silage. Journal of Science of Food and Agriculture, v.54, p.557-568, 1991.

McDONALD, L.C.; McFEETERS, R.F.; DAESCHEL, M.A.; FLEMING, H.P. A differential medium for the enumeration of homofermentative and heterofermentative lactic acid bacteria. Applied and Evironmental Microbiology, v.53, p.1382-1384,1987.

McDONALD, P.; HENDERSON, A.R.; HERON, S.J.E. Biochemistry of silage. 2.ed. Marlow: Chalcombe Publication, 1991. 340p.

McGECHAN, M.B. A review of losses arising during conservation of grass forage: Storage losses. Journal of Agricultural Engineering Research, v.45, p.1-30, 1989.

MONTVILLE, T.J. Principles which influence microbial growth, survival and death in foods. In: DOYLE, M.P.; BEUCHAT, L.R.; MONTEVILLE, T.J. (Ed.) Food microbiology: Fundamentals and frontiers. Washington:ASM Press, 1997. cap.2, p.13-29.

OSTLING, C.; LINDGREN, S. Influences of enterobacteria on the fermentation and aerobic stability of grass silages. Grass and Forage Science, v.50, p.41-47, 1995.

PLAYNE, M.J.; MCDONALD, P. The buffring constituents of herbage and of silage. Journal of Science of Food and Agriculture, v.17, p.264268, 1966.

REIS, S.T. Valor nutricional de gramíneas tropicais em diferentes idades de corte. Lavras: UFLA, 2000. 99p. (Dissertação - Mestrado).

RIBEIRO, K.G.; PEREIRA, O.G.; SOUZA, P.P.S.; CECON, P.R. Composição bromatológica de silagens de Brachiaria decumbens, tratadas com inoculante microbiano, em diferentes idades de corte. In: REUNIÃO ANUAL DA SOCIEDADE BRASILEIRA DE ZOOTECNIA, 39., Recife, 2002 Anais. Recife: SBZ, 2002. 1 CD Rom. 
ROBERTSON, J.B.; VAN SOEST, P.J. The detergent system of analysis and its application to human foods. In: JAMES, W.P.T.; THEANDER, $\mathrm{O}$. (Ed.) The analysis of dietary fiber in food. New York: Marcel Dekker, 1981. p.123-158.

SILVA, C.L. Perfil de fermentação das silagens de capim-Tanzânia com aditivos. Lavras: UFLA, 2002. (Dissertação - Mestrado).

SILVA, D.J. Análise de alimentos: métodos químicos e biológicos. 2.ed. Viçosa: UFV, 1998. 166p.

TILLEY, J.M.A.; TERRY, R.A.A two-stage tecnique for the in vitro digestion of forage crops. Journal of British Grassland, v.18, p.104-111, 1963.

TOSI, H.; SCHOCKEN-ITURRINO, R.P.; RAVAZI, J.P. Presença de Clostridium em silagem de milho colhido em diferentes estágios de desenvolvimento. Pesquisa Agropecuária Brasileira, v.17, p.1133$1136,1982$.

VAN SOEST, P. Nutritional ecology of the ruminant. 2.ed. New York: Cornell University Press, 1994. 476p.
WHITER, A.G.; KUNG Jr., L. The effect of a dry or liquid application of Lactobacillus plantarum MTD1 on the fermentation of alfalfa silage. Journal of Dairy Science, v.84, p.2195-2202, 2001.

WINTERS, A.L; WHITTAKER, P.A.; WILSON, R.K. Microscopic and chemical changes during the first 22 days in Italian ryegrass and cocksfoot silages made in laboratory silos. Grass and Forage Science, v.42, p.191-196, 1987.

WOOLFORD, M.K. The silage fermentation. New York: Marcel Dekker, 1984. 350p.

Received December 12, 2003

Accepted March 07, 2005 